\title{
Artificial diet for laboratory rearing of Condylorrhiza vestigialis (Guenée, 1854) (Lep.: Crambidae)
}

\author{
LUCAS S. CAMPOS ${ }^{1}$, ALOISIO COELHO JR ${ }^{1,2}$ and JOSÉ ROBERTO P. PARRA ${ }^{1}$ \\ 'Departamento de Entomologia e Acarologia, Escola Superior de Agricultura "Luiz de Queiroz"/ \\ ESALQ, Avenida Pádua Dias, 11, Agronomia, 13418-900 Piracicaba, SP, Brazil
}

Manuscript received on March 21, 2016; accepted for publication on September 20, 2016

\begin{abstract}
The Brazilian Poplar Moth, Condylorrhiza vestigialis (Guenée), compromises the wood productivity of poplar trees (Populus sp.), mainly affecting the matchstick industry in southern Brazil. Considering the lack of information on rearing techniques for this insect, the objective of this study was to develop an artificial diet to rear $C$. vestigialis with biological characteristics similar to the wild insects. A properly diet will enable bio-ecological studies and biological control programs using the baculovirus Condylorrhiza vestigialis multiple nucleopolyhedrovirus (CvMNPV). To attain this objective, first, three artificial diets were tested. Only the diet based on corn, wheat germ and yeast as a protein source (Diet 3) was able to supply the nutritional requirements of the moth and support completion of its life cycle. In the second experiment, Diet 3 was compared to the natural diet of $C$. vestigialis. The artificial diet supported a viability of $81 \%$ of the eggs, while only $40 \%$ developed on the natural diet. Life-table data showed the same pattern: the net reproductive rate $(R o)$ of $C$. vestigialis reared on the artificial diet was 401.70 , and on the natural diet was 151.22. The artificial diet is adequate for mass rearing of $C$. vestigialis, to support biological control programs using the baculovirus.
\end{abstract}

Key words: IPM, biological control, forest entomology, baculovirus.

\section{INTRODUCTION}

Poplar trees, Populus spp. (Salicales: Salicaceae), are widely distributed in the Northern Hemisphere, from the tropics to $68^{\circ} \mathrm{N}$ latitude. These trees are generally short-lived due to the incidence of insects and diseases, although their rapid growth often enables them to reach large sizes (Dickmann 2001). The wood is used in a large number of products (Balatinecz and Kretschmann 2001). In Brazil, it is

Correspondence to: Aloisio Coelho Júnior

E-mail: aloisiocoelho@usp.br widely grown in the Iguaçu River Basin (southern Paraná state), and provides raw material for the matchstick industry (Machado 2006).

The largest losses of productivity in poplars are caused mainly by the attack of the defoliating larva Condylorrhiza vestigialis (Guenée, 1854) (Lep.: Crambidae), known as the Brazilian Poplar Moth, which compromises productivity (Diodato 1999). Among the few available methods to control C. vestigialis is the baculovirus Condylorrhiza vestigialis multiple nucleopolyhedrovirus (CvMNPV), a highly specific and effective control for this pest (Castro et al. 2003). 
For large-scale production of the viral extract, large numbers of $C$. vestigialis larvae are needed. To be viable, this mass production must be conducted on an artificial diet (Castro et al. 2003, Corrêa 2006). Few studies have described standard specific diets for rearing C. vestigialis, which has hampered the adoption of biological control for the pest in large areas. Improved techniques to rear C. vestigialis larvae, using an artificial diet, will make it possible to move forward in bio-ecological studies of this pest, since it can be continuously reared in laboratory conditions, without relying on natural populations (Parra 2009), for this purpose the laboratory reared insect, should be similar to the wild, to avoid errors. This rearing method also will aid in large-scale production of the virus for biological-control programs.

Considering the sparse information about a specific artificial diet for rearing $C$. vestigialis, the present study aimed to develop an artificial diet for rearing a population with biological characteristics similar to the wild insects, compared to the natural food of the larvae.

\section{MATERIALS AND METHODS}

COMPARISON OF ARTIFICIAL DIETS FOR

Condylorrhiza vestigialis (GUENÉE, 1854)

Three artificial diets with different sources of protein were assessed (Table I), termed Diet 1 (casein-based), Diet 2 (casein and wheat germbased) prepared with modifications of the diet proposed by Singh (1983), since this diet is used for different orders of insects; and Diet 3 (corn, wheat germ and yeast-based) proposed by Parra and Mihsfeldt (1992) for Diatraea saccharalis Fabricius (Lepidoptera: Crambidae). Each diet was prepared and transferred to 150 glass tubes (replication) plugged with hydrophilic cotton, previously sterilized in an oven at $160^{\circ} \mathrm{C}$ for 1 h. The tubes with the diet were allowed to dry for about $24 \mathrm{~h}$ to remove excess water. A newly hatched larva was placed in each tube, using a soft brush. The tubes were kept in a climate-controlled room with a temperature of $25 \pm 2{ }^{\circ} \mathrm{C}, \mathrm{RH} 60 \pm 10 \%$ and photophase of $14 \mathrm{~h}$.

From the 150 larvae in each treatment, 30 were randomly selected for measuring the width of the cephalic capsules, to determine the instars. These measurements were made daily, always at the same time, using a Wild ${ }^{\circledR}$ (Heerbrugg- Switzerland) digital meter linked to a stereomicroscope. On the $10^{\text {th }}$ day, the phagostimulant effect of the artificial diets was evaluated, based on the start of feeding. The duration and viability of the embryonic, larval and pupal periods were also evaluated. The sex ratio was determined by the formula $\boldsymbol{s} \boldsymbol{r}=\frac{\text { no. of females }}{\text { no. of females }+ \text { no. of males }}$ based on sexual dimorphism in the pupa, as described by Butt and Cantu (1962). Pupae 48 h old were weighed on an analytical balance, and were then placed in individual tubes until the adults emerged.

When the first adults emerged, 25 couples were combined and placed in individual PVC cages measuring $10 \mathrm{~cm} \varnothing$ (diameter) by $22 \mathrm{~cm} \mathrm{~h}$ and lined with paper sheets, and kept in a room with a temperature of $25 \pm 2{ }^{\circ} \mathrm{C}$, RH $60 \pm 10 \%$ and photophase of $14 \mathrm{~h}$, feed with a $10 \%$ honey solution (in water), offered to the moths through cotton dental roll inserted into a plastic tube. The preoviposition period, daily egg laying capacity, egg viability, and lifespan of adults were evaluated. All experimental design was completely randomized.

\section{COMPARISON OF NATURAL AND ARTIFICIAL DIETS AS QUALITY-CONTROL CRITERION FOR $C$. vestigialis}

The development of $C$. vestigialis was observed and compared on a natural diet (poplar sapling leaves) and Diet 3 (corn, wheat germ and yeastbased), which was determined to be appropriate in the first experiment (see results, Figs. 1 and 2). For the natural diet, young poplar leaves were washed 
TABLE I

Composition of diets evaluated for the development of Condylorrhiza vestigialis in the laboratory.

\begin{tabular}{|c|c|c|c|c|c|c|}
\hline \multirow{2}{*}{ Components } & \multicolumn{2}{|c|}{ Diet 1} & \multicolumn{2}{|c|}{ Diet 2} & \multicolumn{2}{|c|}{ Diet 3} \\
\hline & Amount & $\%$ & Amount & $\%$ & Amount & $\%$ \\
\hline Casein & $28 \mathrm{~g}$ & 3.9 & $28 \mathrm{~g}$ & 3.5 & - & - \\
\hline Wheat germ & - & - & $24 \mathrm{~g}$ & 3 & $60 \mathrm{~g}$ & 5.7 \\
\hline Cornmeal & - & - & - & - & $80 \mathrm{~g}$ & 7.6 \\
\hline Yeast & - & - & - & - & $30 \mathrm{~g}$ & 2.9 \\
\hline Wheat germ oil & $0.3 \mathrm{ml}$ & 0.04 & - & - & - & - \\
\hline Sunflower oil & - & - & - & - & $4 \mathrm{~g}$ & 0.4 \\
\hline Cellulose & $10 \mathrm{~g}$ & 1.4 & $80 \mathrm{~g}$ & 9.9 & - & - \\
\hline Sucrose & $24 \mathrm{~g}$ & 3.4 & $24 \mathrm{~g}$ & 3 & $26 \mathrm{~g}$ & 2.5 \\
\hline Glucose & $4 \mathrm{~g}$ & 0.6 & $4 \mathrm{~g}$ & 0.5 & - & - \\
\hline Vitamin solution* & $16 \mathrm{ml}$ & 2.2 & $16 \mathrm{ml}$ & 2 & $16 \mathrm{ml}$ & 1.5 \\
\hline Wesson salts & $8 \mathrm{~g}$ & 1.1 & $8 \mathrm{~g}$ & 1 & $7 \mathrm{~g}$ & 0.7 \\
\hline Sorbic acid & $0.2 \mathrm{~g}$ & 0.03 & $0.2 \mathrm{~g}$ & 0.02 & - & - \\
\hline Ascorbic acid & - & - & - & - & $3 \mathrm{~g}$ & 0.3 \\
\hline Linoleic acid & - & - & $0.2 \mathrm{~g}$ & 0.02 & - & - \\
\hline Benzoic acid & - & - & - & - & $2 \mathrm{~g}$ & 0.2 \\
\hline Cholesterin & - & - & $0.4 \mathrm{~g}$ & 0.05 & - & - \\
\hline $\begin{array}{l}\text { Methyl parahydroxy- } \\
\text { benzoate (Nipagin) }\end{array}$ & $1.5 \mathrm{~g}$ & 0.2 & $1.5 \mathrm{~g}$ & 0.2 & $2 \mathrm{~g}$ & 0.2 \\
\hline Tetracycline & $0.1 \mathrm{~g}$ & 0.01 & $0.1 \mathrm{~g}$ & 0.01 & - & - \\
\hline Formaldehyde $37 \%$ & - & & - & - & $2 \mathrm{ml}$ & 0.2 \\
\hline Carrageenan & $20 \mathrm{~g}$ & 2.8 & $20 \mathrm{~g}$ & 2.5 & $15 \mathrm{~g}$ & 1.4 \\
\hline Distilled water & $600 \mathrm{ml}$ & 84.3 & $600 \mathrm{ml}$ & 74.4 & $800 \mathrm{ml}$ & 76.4 \\
\hline
\end{tabular}

*Vitamin solution extract from Parra (2007): Dry part (niacinamide $1.00 \mathrm{~g}$, calcium pantothenate $1.00 \mathrm{~g}$, riboflavin $0.50 \mathrm{~g}$, thiamine $0.25 \mathrm{~g}$, pyridoxine 0.25 $\mathrm{g}$, folic acid $0.10 \mathrm{~g}$, biotin $0.02 \mathrm{mg})$; Liquid part (vitamin B12 (1000 mg / ml) $2.00 \mathrm{ml}$ ). Mix the dry and liquid parts in $1000 \mathrm{ml}$ distilled water to prepare the vitamin solution.

with distilled water and transferred to 150 plastic Petri dishes (replication) with $5 \mathrm{~cm} \varnothing$, containing moistened filter paper. A newly hatched larva was placed in each Petri dish, using a soft brush. Thirty of these larvae were randomly selected to measure the width of the cephalic capsules, which was done every day at the same time, using a Wild $\mathbb{R}$ digital meter linked to a stereomicroscope. The leaves were changed every two days until the larvae completed the 3rd instar, after which the leaves were changed daily, due to the high food consumption in the last instars.
Larvae of $C$. vestigialis were reared on Diet 3 according to the procedures described before. The biological parameters of duration and viability of eggs, larvae, pre-pupae and pupae, sex ratio, pupal weight, duration of the pre-oviposition period, fertility, and lifespan of adults were also analyzed as above. In addition, we determined the number of individuals with morphological deformations; and the number of mating's, assessed by counting the spermatophores inserted in the female copulation bursa (Milano et al. 2008). Based on egg-adult duration, viability, sex ratio and fertility, a life table 
was constructed (Silveira Neto et al. 1976) and used to compare the two diets (natural and artificial). The entire experiment was conducted under controlled laboratory conditions $\left(25 \pm 2^{\circ} \mathrm{C}, \mathrm{RH} 60 \pm 10 \%\right.$ and photophase of $14 \mathrm{~h}$ ). All experimental design was completely randomized.

\section{DATA ANALYSIS}

The number of instars was defined according to Dyar's rule, using a graph of frequency distribution of the cephalic capsule widths and their respective linear regressions; an ANOVA of the linear regression was performed at the 5\% significance level (Parra and Haddad 1989).

The data from laboratory rearing method were analyzed using generalized linear models (GLM) (Nelder and Wedderburn 1972); the number of adults with deformations, sex ratio, larval and pupal viability through a binomial distribution; and the data for fertility analysis, copulation number and pupal weight by quasi-Poisson distribution. The quasi-binomial distribution was used for analysis of the egg viability. The "F" value was calculated by ANOVA of the models. The goodness of fit was determined using a half-normal graph of probabilities with a simulation envelope (Demétrio and Hinde 1997, Hinde and Demétrio 1998). When there was a significant difference between treatments, multiple comparisons (Tukey test, $P<0.05)$ were done with the glht function from the multcomp package (Hothorn et al. 2008) with "p" adjusted by the single-step method. The data for durations of egg, larva, pre-pupa, pupa, preoviposition stage and longevity were analyzed using the survival curve, where the means and standard errors were calculated with the KaplanMeier estimator with the corresponding survival function; and the means compared by Log-rank test $(P<0.05)$. All analyses were performed using the $\mathrm{R}$ statistical program (The R Foundation for Statistical Computing; http://www.R-project. org). The parameters estimated from the life table were compared using a Jackknife analysis; each parameter was compared using the $95 \%$ confidence interval.

\section{RESULTS AND DISCUSSION}

COMPARISON OF ARTIFICIAL DIETS FOR

Condylorrhiza vestigialis (GUENÉE, 1854)

For Diet 1 (casein-based), the mortality recorded on the 10 th day was $73.5 \%$, and on the 15 th day all larvae had died before reaching the 3rd instar, with a prolonged development period of up to 8 days in the 2 nd instar. For Diet 2 (casein and wheat germ-based), mortality was $33.1 \%$ on the 10 th day, and all the larvae had died by the 15 th day, before reaching the 4th instar. Diet 3 (corn, wheat germ and yeast-based) was the only one where the larvae completed their development; on the 10th day the mortality rate was $2 \%$; on the 13 th day, pre-pupae were observed; and after 22 days the first adults emerged. Therefore, Diet 3 has a good phagostimulant action, with $98 \%$ of the larvae starting to feed, unlike Diets 1 and 2 where only $26.5 \%$ and $66.9 \%$ of the larvae started feeding, respectively.

On Diet 3, the larval stage had 5 instars (Fig. 1), with mean durations of 3, 2, 1.6, 2, and 3.5 days, respectively, for instars 1-5 (Fig. 1 and 2). The pre-pupal stage lasted 24 hours; the pupal stage averaged 7.8 days (Fig. 2). In this diet, the viability of the larval and pupal stages was $97.3 \%$ and $95.1 \%$ respectively. The percentage of adults emerged without deformation was $96.3 \%$, with a sex ratio of 0.5 (Table II). The lifespans of males and females emerged from Diet 3 were 17.56 and 13.60 days, respectively, with a pre-oviposition period of 3.08 days. The female egg production capacity was 964.4 eggs, on average, and the viability of these eggs was $92.1 \%$.

The egg viability on Diet 3 was $82.2 \%$, higher than the $75 \%$ considered the minimum threshold required for an artificial diet to be considered adequate for insect laboratory rearing (Singh 1977). 


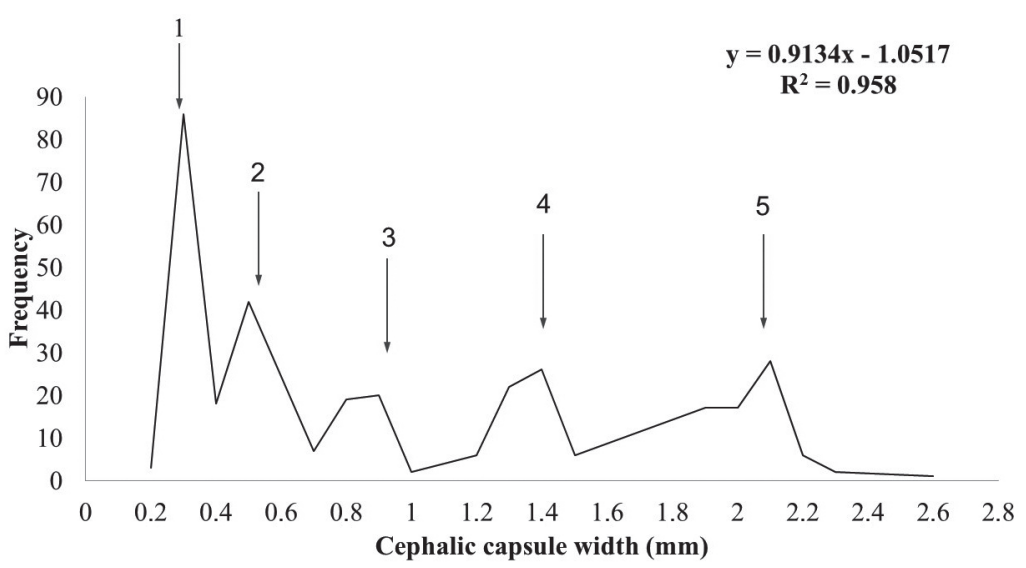

Figure 1 - Larval instar number of Condylorrhiza vestigialis and the cephaliccapsule widths on the corn, wheat germ and yeast-based Diet 3 . Temperature $25 \pm$ $2{ }^{\circ} \mathrm{C}$, RH $60 \pm 10 \%$ and photophase of $14 \mathrm{~h}$. Arrows indicate the instars.

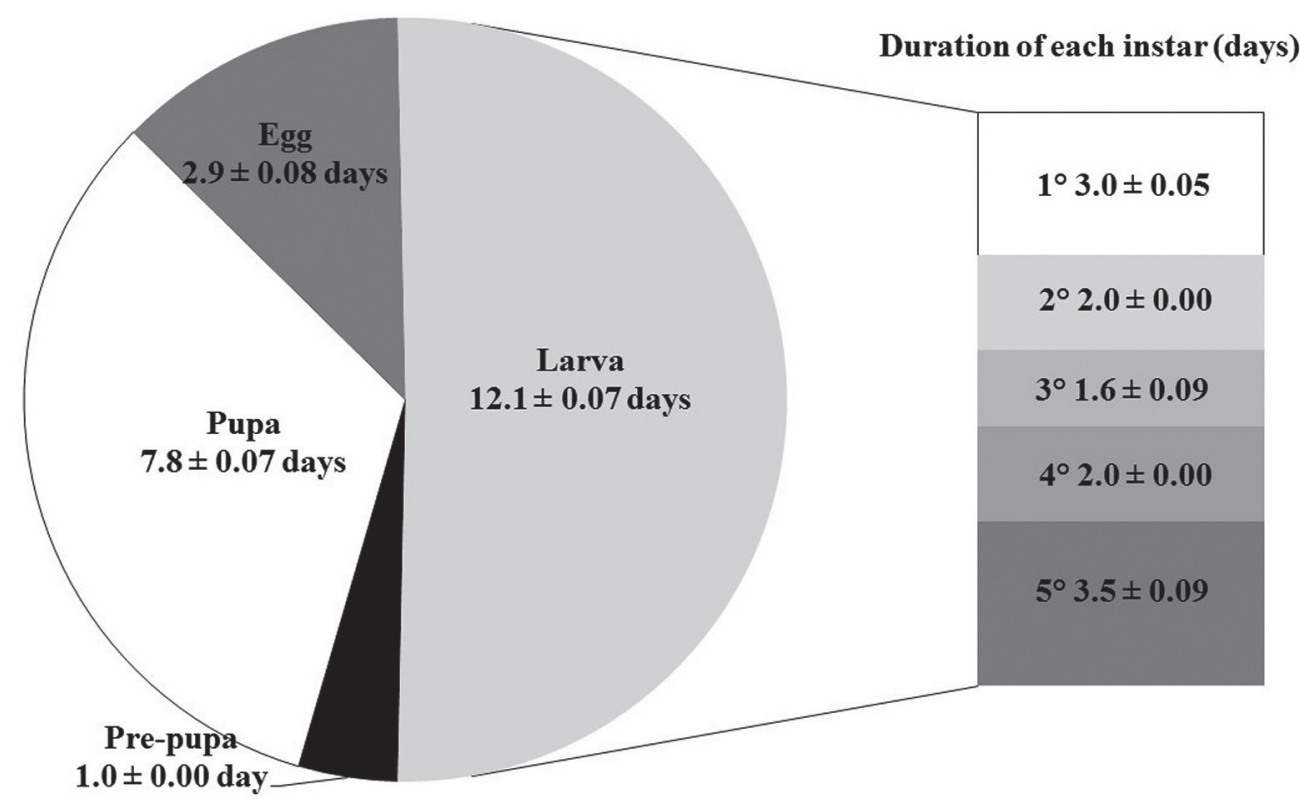

Figure 2 - Biological cycle for Condylorrhiza vestigialis (egg to adult, $\mathrm{N}=30$ ) with the duration of each stage and the standard error of the mean, on Diet 3- corn, wheat germ and yeast-based. Temperature 25 $\pm 2{ }^{\circ} \mathrm{C}$, RH $60 \pm 10 \%$ and photophase of 14 hours.

TABLE II

Condylorrhiza vestigialis pupal weight, pre-oviposition period, sex ratio, lifespan of females and males, fertility, and mean egg viability observed on Diet 3 (corn, wheat germ and yeast-based).

\begin{tabular}{cccccccc}
\hline \multicolumn{2}{c}{$\begin{array}{c}\text { Pupal weight }(\mathrm{mg}) \\
+\end{array}$} & $\begin{array}{c}\text { Pre-oviposition } \\
\text { period (days) }\end{array}$ & $\begin{array}{c}\text { Sex } \\
\text { ratio }\end{array}$ & $\begin{array}{c}\text { Lifespan (days) } \\
\text { o }\end{array}$ & $\begin{array}{c}\text { Fertility } \\
\text { Egg viability (\%) }\end{array}$ \\
\hline $\begin{array}{c}126.8 \pm 1.4 \\
(\mathrm{~N}=72)\end{array}$ & $\begin{array}{c}124.5 \pm 1.3 \\
(\mathrm{~N}=71)\end{array}$ & $\begin{array}{c}3.08 \pm 0.31 \\
(\mathrm{~N}=30)\end{array}$ & $\begin{array}{c}0.5 \\
(\mathrm{~N}=143)\end{array}$ & $\begin{array}{c}13.6 \pm 0.4 \\
(\mathrm{~N}=25)\end{array}$ & $\begin{array}{c}17.6 \pm 0.5 \\
(\mathrm{~N}=25)\end{array}$ & $\begin{array}{c}964.48 \pm 83.06 \\
(\mathrm{~N}=25)\end{array}$ & $\begin{array}{c}92.05 \pm 0.04 \\
(\mathrm{~N}=25)\end{array}$ \\
\hline
\end{tabular}


COMPARISON REARING ON NATURAL AND ARTIFICIAL DIETS AS QUALITY-CONTROL CRITERIA FOR C. vestigialis

The number of instars (five) was the same on the natural and artificial diets (Fig. 3). Considering that the number of instars is one parameter that indicates nutritional adequacy (Parra et al. 2009), Diet 3 demonstrated its nutritional quality for $C$. vestigialis. The results for instar determination on both diets had an $\mathrm{R}^{2}$ coefficient higher than $95 \%$ (Fig. 3). No difference was found for the embryonic period $\left(\chi^{2}=1.7 ; \mathrm{df}=1 ; P=0.19\right)$ that was around three days. The durations of the larval, pre-pupal and pupal stages of $C$. vestigialis were shorter on the natural than on the artificial diet (larva- $\chi^{2}=$ 63.1; df $=1 ; P<0.001 /$ pre-pupa- $\chi^{2}=63.6 ; \mathrm{df}=1$; $P<0.001 /$ pupa- $\chi^{2}=33.2 ; \mathrm{df}=1 ; P<0.001$ ) (Fig. 4). The larval stage on the natural diet was about two days shorter than on the artificial diet. The preoviposition period was about four days without difference between natural and artificial diet $\left(\chi^{2}=\right.$ $1.9 ; \mathrm{df}=1 ; P=0.16$ ) (Fig. 4).

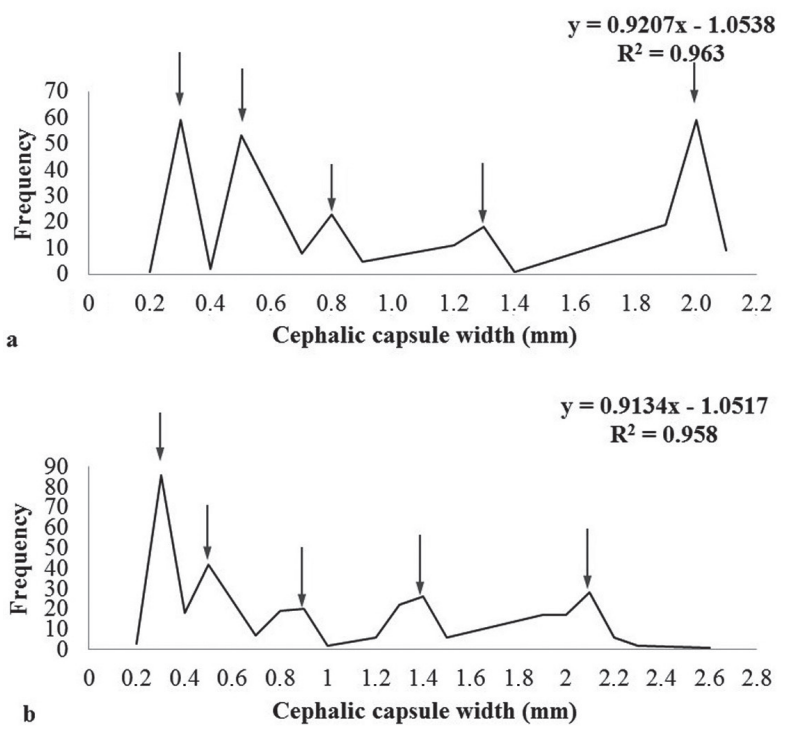

Figure 3 - Larval instars of Condylorrhiza vestigialis and the width of the cephalic capsule on natural diet (a) and artificial $\operatorname{diet}$ (b). Temperature $25 \pm 2{ }^{\circ} \mathrm{C}, \mathrm{RH} 60 \pm 10 \%$ and photophase of $14 \mathrm{~h}$. Arrows indicate the instars.

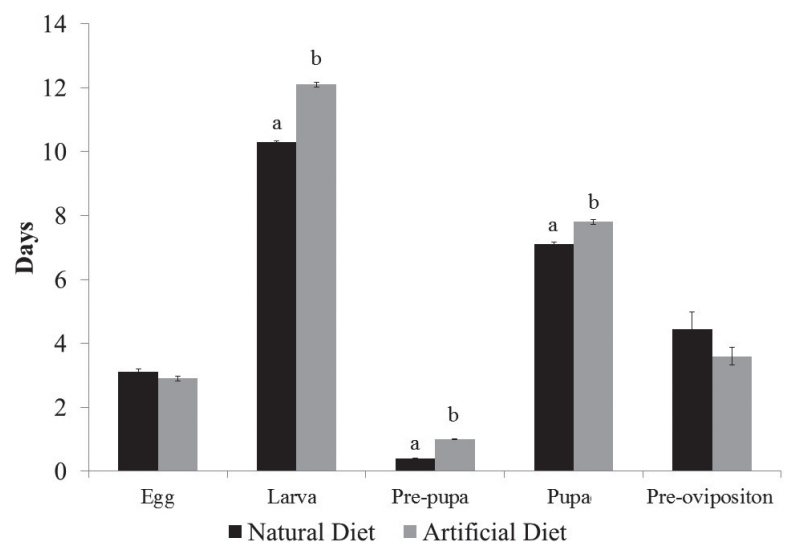

Figure 4 - Duration of the development stages (egg, larva, pre-pupa, pupa, $\mathrm{N}=30$ ) and pre-oviposition of Condylorrhiza vestigialis on natural (poplar leaves) and artificial (corn, wheat germ and yeast-based) diets; temperature $25 \pm 2{ }^{\circ} \mathrm{C}$, RH 60 $\pm 10 \%$ and photophase of $14 \mathrm{~h}$. Means followed by the same letter do not differ by the log-rank test $(P>0.05)$.

Adults from larvae fed the artificial diet showed better reproductive performance. The estimated number of mating's per female reared on the artificial diet was higher than the females on the natural diet, about three copulations more per female $(\mathrm{F}=25.49$; df $=1 ; P<0.001)$ (Table III). No morphological deformities were recorded in adults reared on natural diet while five adults emerged with deformed (specially on wings) on Diet $3\left(\chi^{2}=7.87 ; \mathrm{df}=1 ; P=0.0087\right)$. The egg production of females emerged from larvae fed on the artificial diet was 1.7 times higher compared to females from the natural diet. The mean number of eggs laid by females given the artificial diet was 965 (F = 14.59; df =1; $P=0.001$ ) (Table III). The higher posture capacity may be a reflection of the pupal weight, since pupae (female) from larvae fed the artificial diet were nearly $20 \mathrm{mg}$ heavier than larvae fed the natural diet $(\mathrm{F}=70.9 ; \mathrm{df}=1$; $P=0.001$ ) (Table III). Daumal and Boinel (1994) found a direct relationship between the weight of insects and their fertility.

The adult lifespan was not affected by the diet on which the insect was reared (Table III). On both diets, males lived longer than females $\left(\chi^{2}=31.6\right.$; $\mathrm{df}$ 
$=1 ; P<0.01)$. The shorter lifespan of females may be related to energy expenditure for reproduction. Coelho Jr and Parra (2013) observed the same pattern for Anagasta kuehniella (Zeller) lifespan.
The sex ratio of individuals from the natural diet was 0.53 , and 0.49 for individuals reared on the artificial diet; these values are statistically similar $(\mathrm{F}=0.36 ; \mathrm{df}=1 ; P=0.54)$.

TABLE III

Female pupal weight, sex ratio, number of deformed adults, mean number of copulations, fertility, and lifespan of females and males of Condylorrhiza vestigialis reared on natural and artificial diets.

\begin{tabular}{|c|c|c|c|c|c|c|c|}
\hline \multirow[b]{2}{*}{ Treatments } & \multirow{2}{*}{$\begin{array}{c}\text { Female pupal } \\
\text { wt. }^{1}(\mathrm{mg})\end{array}$} & \multirow[b]{2}{*}{ Sex ratio } & \multirow{2}{*}{$\begin{array}{l}\text { No. of } \\
\text { deformed } \\
\text { adults }^{1}\end{array}$} & \multirow{2}{*}{ Mean no. of matings ${ }^{1 *}$} & \multirow{2}{*}{ Fertility ${ }^{1}$} & \multicolumn{2}{|c|}{ Lifespan $^{2}$ (days) } \\
\hline & & & & & & 요 & $\hat{\sigma}$ \\
\hline Natural diet & $\begin{array}{c}107.4 \pm 1.9 \mathrm{a} \\
(\mathrm{N}=143)\end{array}$ & $\begin{array}{r}0.53 \pm \\
(\mathrm{N}=1\end{array}$ & $\begin{array}{c}0 \pm 0.00 \mathrm{a} \\
(\mathrm{N}=138)\end{array}$ & $\begin{array}{c}1.80 \pm 0.34 \text { a }(1-6)^{* * *} \\
(\mathrm{~N}=25)\end{array}$ & $\begin{array}{r}568.1 \\
(\mathrm{~N}=\end{array}$ & $\begin{array}{c}13.9 \pm 0.7 \mathrm{aA} \\
(\mathrm{N}=25)\end{array}$ & $\begin{array}{c}18.6 \pm 1.3 \mathrm{aB} \\
(\mathrm{N}=25)\end{array}$ \\
\hline Artificial diet 3 & $\begin{array}{c}126.8 \pm 1.4 b \\
(\mathrm{~N}=134)\end{array}$ & $\begin{array}{c}0.49 \pm 0.04 \\
(\mathrm{~N}=134)\end{array}$ & $\begin{array}{l}5 \pm 0.02 \mathrm{~b} \\
(\mathrm{~N}=134)\end{array}$ & $\begin{array}{c}4.76 \pm 0.46 \mathrm{~b}(1-9)^{* *} \\
(\mathrm{~N}=25)\end{array}$ & $\begin{array}{c}964.5 \pm 83.1 \mathrm{~b} \\
(\mathrm{~N}=25)\end{array}$ & $\begin{array}{c}13.6 \pm 0.4 \mathrm{aA} \\
(\mathrm{N}=25)\end{array}$ & $\begin{array}{c}17.6 \pm 0.5 \mathrm{aB} \\
(\mathrm{N}=25)\end{array}$ \\
\hline
\end{tabular}

${ }^{1}$ Means followed by the same letter do not differ by Tukey test $(P<0.05)$.

${ }^{2}$ Means followed by the same lower-case letter in a column and the same capital letter on a line do not differ by log-rank test $(P$ $<0.05)$.

* Determined by counting the number of spermatophores in the female copulation bursa. ** Min. and max. no. of spermatophores in the bursa.

The viability of the egg stage from females reared on the natural diet was less than $50 \%$, lower than eggs laid by females fed the artificial diet $(88 \%)(\mathrm{F}=30.6$; df $=1 ; P<0.001)$ (Table IV). Possibly, the high viability values obtained on artificial diet are related to the fact that artificial diets have more quantity and equilibrium of all nutrients required for the insect development. The viability of the other development stages was always higher than $90 \%$, with no difference between the natural and artificial diets (larva- $\chi^{2}=$ 3.53; df $=1 ; P=0.06 /$ pupa- $\chi^{2}=0.27 ; \mathrm{df}=1 ; P$ $=0.60$ ). The higher viability of the egg stage of C. vestigialis fed the artificial diet was one of the key factors indicating the suitability of this diet for the species, considering that the estimated total viability was $81 \%$, higher than Singh (1977) recommendation (75\%), while for the natural diet the total viability was only $40 \%$.

These biological parameters produced a net reproductive rate $(R o)$, i.e. how much the population increases in each generation, of 151.22 on the natural diet and 401.70 on the artificial diet.
TABLE IV

Viability (\%) of egg, larval, and pupal stages of Condylorrhiza vestigialis on natural and artificial diets.

\begin{tabular}{lccc}
\hline Treatment & Egg $(\%)$ & Larvae (\%) & Pupae (\%) \\
\hline Natural diet & $46.0 \pm 3.9 \mathrm{a}^{\mathbf{1}}$ & $92.7 \pm 2.1$ & $96.4 \pm 1.6$ \\
& $(\mathrm{~N}=25)$ & $(\mathrm{N}=150)$ & $(\mathrm{N}=145)$ \\
Artificial & $88.0 \pm 7.8 \mathrm{~b}$ & $97.3 \pm 1.3$ & $95.1 \pm 1.8$ \\
diet 3 & $(\mathrm{N}=25)$ & $(\mathrm{N}=150)$ & $(\mathrm{N}=139)$ \\
\hline
\end{tabular}

${ }^{1}$ Means followed by the same letter do not differ by the Tukey test $(P<0.05)$.

The finite rate of increase $\lambda$ for the artificial diet was 1.25 , higher than 1.21 for the natural diet; these values are statistically different (Table V). Accordingly, the artificial diet developed by Parra and Mihsfeldt (1992) for D. saccharalis rearing, with corn, wheat germ and yeast as the protein source, can replace the natural diet (poplar leaves) for mass production of $C$. vestigialis larvae, to support industrial production of the baculovirus to be used as a pest control in field conditions. Taking into account the higher $R o$ of the artificial diet and the viability above $75 \%$, this contribution describes the first practical artificial diet for C. vestigialis. 
TABLE V

Fertility life table of Condylorrhiza vestigialis from the parameters of moths reared on natural and artificial diets. Mean generation time $(T)$, net reproductive rate $(R o)$, intrinsic rate of increase $\left(r_{m}\right)$ and finite rate of increase $(\lambda)$.

\begin{tabular}{lcccc}
\hline \multirow{2}{*}{ Treatments } & \multicolumn{4}{c}{ Parameters } \\
& $T^{1}$ & $R o^{1}$ & $r_{m}{ }^{1}$ & $\lambda^{1}$ \\
\hline Natural diet & $26.06 \mathrm{a}$ & $151.22 \mathrm{a}$ & $0.192 \mathrm{a}$ & $1.21 \mathrm{a}$ \\
Artificial diet 3 & $26.84 \mathrm{~b}$ & $401.70 \mathrm{~b}$ & $0.223 \mathrm{~b}$ & $1.25 \mathrm{~b}$ \\
\hline
\end{tabular}

${ }^{1}$ Parameters followed by the same letter do not differ by the Jackknife test.

\section{ACKNOWLEDGMENTS}

We thank Janet W. Reid, JWR Associates, for the English revision and the company Swedish Match Brasil for providing the biological material. We also thank the Fundação de Amparo à Pesquisa do Estado de São Paulo (FAPESP; process no. 2009/01401-3) and the Instituto Nacional de Ciência e Tecnologia Semioquímicos na Agricultura (INCT; process no. 573761/2008-6) for financial support.

\section{REFERENCES}

BALATINECZ JJ AND KRETSCHMANN DE. 2001. Properties and utilization of poplar wood. In: Dickmann DI ET AL. (Eds), Poplar culture in North America. NRC Research Press, Ottawa, Canada, p. 277-291.

BUTT BA AND CANTU E. 1962. Sex determination of lepidopterous pupae. USDA, Agricultural Research Service Report 33-75. Washington, USA.

CASTRO MEB, RIBEIRO ZMA, SOUZA ML, SOUSA NJ AND MOSCARDI F. 2003. Caracterização morfológica do vírus da lagarta-do-álamo Condylorrhiza vestigialis (Guenée, 1854) (Lepidoptera: Noctuidae) p. 72. In: Proceedings, VIII Simpósio de Controle Biológico, 22 26 June 2003, São Pedro, Brasil, Sociedade Entomológica do Brasil, Londrina, Brasil.

COELHO JR A AND PARRA JRP. 2013. The effect of rearing in different temperature regimes on the reproduction of Anagasta kuehniella (Lepidoptera: Pyralidae). Environ Entomol 42: 799-804.

CORRÊA FASF. 2006. Criação em laboratório de Condylorrhiza vestigialis (Guené, 1854) (Lepidoptera: Crambidae) com diferentes dietas artificiais. M.Sc Dissertation, Universidade Federal do Paraná, Curitiba, Brasil. (Unpublished).

DAUMAL J AND BOINEL H. 1994. Variability in fecundity and plasticity of oviposition behavior in Anagasta kuehniella (Lepidoptera: Pyralidae). Ann Entomol Soc Am 87: 250-256.
DEMÉTRIO CGB AND HINDE J. 1997. Half-normal plots and overdispersion. Glim Newslett 27: 19-26.

DICKMANN DI. 2001. An overview of the genus Populus. In: Dickmann DI ET AL. (Eds), Poplar culture in North America. NRC Research Press, Ottawa, Canada, p. 1-42.

DIODATTO M. 1999. Bioecologia, aspectos morfológicos e consumo de Condylorrhiza vestigialis (Guenée, 1854) (Lepidoptera: Crambidae) em Populus deltoides Bart. Ex Marsh. (Salicaceae). Ph.D. Thesis, Universidade Federal do Paraná, Curitiba, Brasil.

HINDE J AND DEMÉTRIO CGB. 1998. Overdispersion: models and estimation. Comput Stat Data Anal 27: 151170.

HOTHORN T, BRETZ F AND WESTFALL P. 2008. Simultaneous inference in general parametric. Models Biom J 50: 346-363.

MACHADO EB. 2006. Controle de Condylorrhiza vestigialis (Guenée, 1854) (Lepidoptera: Crambidae), a mariposa do álamo, com o uso de $C$. vestigialis multiple nucleopolyhedrovírus em condições de laboratório e campo. M.Sc Dissertation, Universidade Federal do Paraná, Curitiba, Brasil. (Unpublished).

MILANO P, BERTI FILHO E, PARRA JRP AND CÔNSOLI FL. 2008. Influência da temperatura na freqüência de cópula de Anticarsia gemmatalis Hübner e Spodoptera frugiperda (J.E.Smith) (Lepidoptera: Noctuidae). Neotrop Entomol 37: 528-535.

NELDER JAAND WEDDERBURN RWM. 1972. Generalized linear models. J R Stat Soc 135: 370-384.

PARRA JRP. 2007. Técnicas de criação de insetos para programas de controle biológico. FEALQ, Piracicaba, Brasil.

PARRA JRP. 2009. The evolution of artificial diets and their interactions in science and technology. In: Panizzi AR and Parra JRP (Eds), Insect bioecology and nutrition for intregrated pest management. CRC Press, Boca Raton, USA, p. 51-92.

PARRA JRP AND HADDAD ML. 1989. Determinação do número de ínstares de insetos. FEALQ, Piracicaba, Brasil.

PARRA JRP AND MIHSFELDT LH. 1992. Comparison of artificial diet for rearing the sugarcane borer. In: Anderson TE and Leppla NC (Eds), Advances in insect rearing for research \& pest management. Westview Press, Bolder, USA, p. 195-209.

PARRA JRP, PANIZZI AR AND HADDAD ML. 2009. Nutritional indices for measuring insect food intake and utilization. In: Panizzi AR and Parra JRP (Eds), Insect bioecology and nutrition for intregrated pest management. CRC Press, Boca Raton, USA, p. 13-49.

SILVEIRA NETO S, NAKANO O, BARBIN D AND VILLA NOVA NA. 1976. Manual de Ecologia dos Insetos. Ceres, Piracicaba, SP.

SINGH P. 1977. Artificial diets for insects, mites, and spiders. Plenum, New York, USA, 594 p.

SINGH P. 1983. A general purpose laboratory diet mixture for rearing insects. Insect Sci Appl 4: 357-362. 